\title{
THE EFFECTIVENESS OF DEEP TRANSVERSE FRICTION MASSAGE FOR THE TREATMENT OF MEDIAL MENISCOTIBIAL LIGAMENT INJURY IN A FEMALE FOOTBALL PLAYER: A CASE STUDY
}

\section{SKUTECZNOŚĆ GŁĘBOKIEGO MASAŻU POPRZECZNEGO W LECZENIU USZKODZENIA WIĘZADŁA ŁĄKOTKOWO-PISZCZELOWEGO PRZYŚRODKOWEGO U ZAWODNICZKI PIŁKI NOŻNEJ: STUDIUM PRZYPADKU}

\author{
Kamil Zaworski ${ }^{1(A, B, C, D, E, F)}$ \\ ${ }^{1}$ Pope John Paul II State School of Higher Education in Biała Podlaska, Poland
}

Authors' contribution Wkład autorów: A. Study design/planning zaplanowanie badań B. Data collection/entry zebranie danych C. Data analysis/statistics dane - analiza i statystyki D. Data interpretation interpretacja danych E. Preparation of manuscript przygotowanie artykułu F. Literature analysis/search wyszukiwanie $\mathrm{i}$ analiza literatury G. Funds collection zebranie funduszy
Tables: 2

Figures: 3

References: 24

Submitted: 2020 March 25

Accepted: 2020 Apr 21

\section{Summary}

Background. The injury to medial meniscotibial ligament (MTL) is a cause of pain in the medial articulatio genus which is rarely discussed in the literature. The paper examines the effectiveness of deep transverse friction massage (DTFM) in the treatment of injury to the medial meniscus-tibial ligament in a female football player.

Material and methods. A case study concerned a patient (22 years old) who is a football player on the position of striker. She has been complaining about the pain in the right, medial articulatio genus for five days. Deep transverse friction massage (DTFM) was applied in the treatment. A total of 9 procedures was conducted (3 times a week) throughout three weeks. The first DTFM session lasted 2 minutes and the time was systematically extended during further sessions until it reached 15 minutes. Visual Analogue Scale (VAS), modified Laitinen Pain Questionnaire and countermovement jump test (CMJ) on the dynamometric platform were applied to evaluate the effectiveness of the treatment.

Results. Having completed the treatment, a decrease of pain measured by the means of VAS and Laitinen Pain Questionnaire was reported. There was also improvement in limb symmetry index in all phases of the test carried out on the dynamometric platform.

Conclusions. The results demonstrate that DTFM may be an effective method of treatment for MTL injuries. Conducting further research on a bigger study group is necessary.

Keywords: knee joint, massage, ligament, meniscotibial ligament, injury

\section{Streszczenie}

Wprowadzenie. Rzadko opisywaną w literaturze przyczyną bólu strony przyśrodkowej stawu kolanowego jest uszkodzenie więzadła łakotkowo-piszczelowego przyśrodkowego (MTL). Celem artykułu jest przedstawienie skuteczność głębokiego masażu poprzecznego (GMP) w leczeniu uszkodzenia więzadła łąkotkowo-piszczelowego przyśrodkowego u zawodniczki piłki nożnej.

Materiał i metody. Studium przypadku dotyczyło pacjentki (22 lata) będącej zawodniczką piłki nożnej na pozycji napastniczki. Od pięciu dni skarżyła się na ból przyśrodkowej strony stawu kolanowego prawego. W leczeniu wykorzystano głęboki masaż poprzeczny (GMP). Łącznie wykonano 9 zabiegów (3 razy w tygodniu) przez okres trzech tygodni. Czas GMP w trakcie pierwszej sesji wynosił 2 minuty i był systematycznie wydłużany w trakcie kolejnych spotkań do 15 min. Do oceny skuteczności zastosowanej metody wykorzystano skalę VAS, zmodyfikowany kwestionariusz Laitinena oraz test skoku pionowego (CMJ) na platformie dynamometrycznej.

Wyniki. Po zakończeniu leczenia odnotowano spadek dolegliwości bólowych mierzony za pomocą VAS i kwestionariusza Laitinena oraz poprawę wskaźnika symetryczności we wszystkich fazach testu przeprowadzonego na platformie dynamometrycznej.

Wnioski. Uzyskane wyniki w badaniach własnych wskazują, że GMP może być skuteczną metodą leczenia uszkodzeń MTL. Istnieje potrzeba prowadzenia dalszych badań na większej grupie badanej.

Słowa kluczowe: staw kolanowy, masaż, więzadło, więzadło łąkotkowo-piszczelowe, uraz 


\section{Introduction}

Interest in female football has been recently increasing. The discipline is associated with a high risk of injuries because of the intensiveness of physical effort combined with sudden changes in movement direction [1, 2]. 50$65 \%$ of all injuries in football are connected with lower limbs [3, 4]. Articulatio genus injuries are associated with ligamentous structures in 40\%. The most common injuries occur to the anterior cruciate ligament (ACL) $46 \%$ and medial collateral ligament (MCL) - 29\% [5]. Injury to medial meniscotibial ligament (MTL) also known as the medial coronary ligament is a cause that is rarely described in literature [6, 7]. This ligament consists of several thick fragments of fibrous layers of the articular capsule and creates the deep layer of the medial collateral ligament (dMCL - deep medial collateral ligament) [8-10]. The ligament is attached to the medial meniscus on its length and the plateau of the tibia. Meniscotibial ligaments create a stabilization system on the entire perimeter of the medial meniscus and control the external rotation of the lower leg [11,12] (Figure 1).

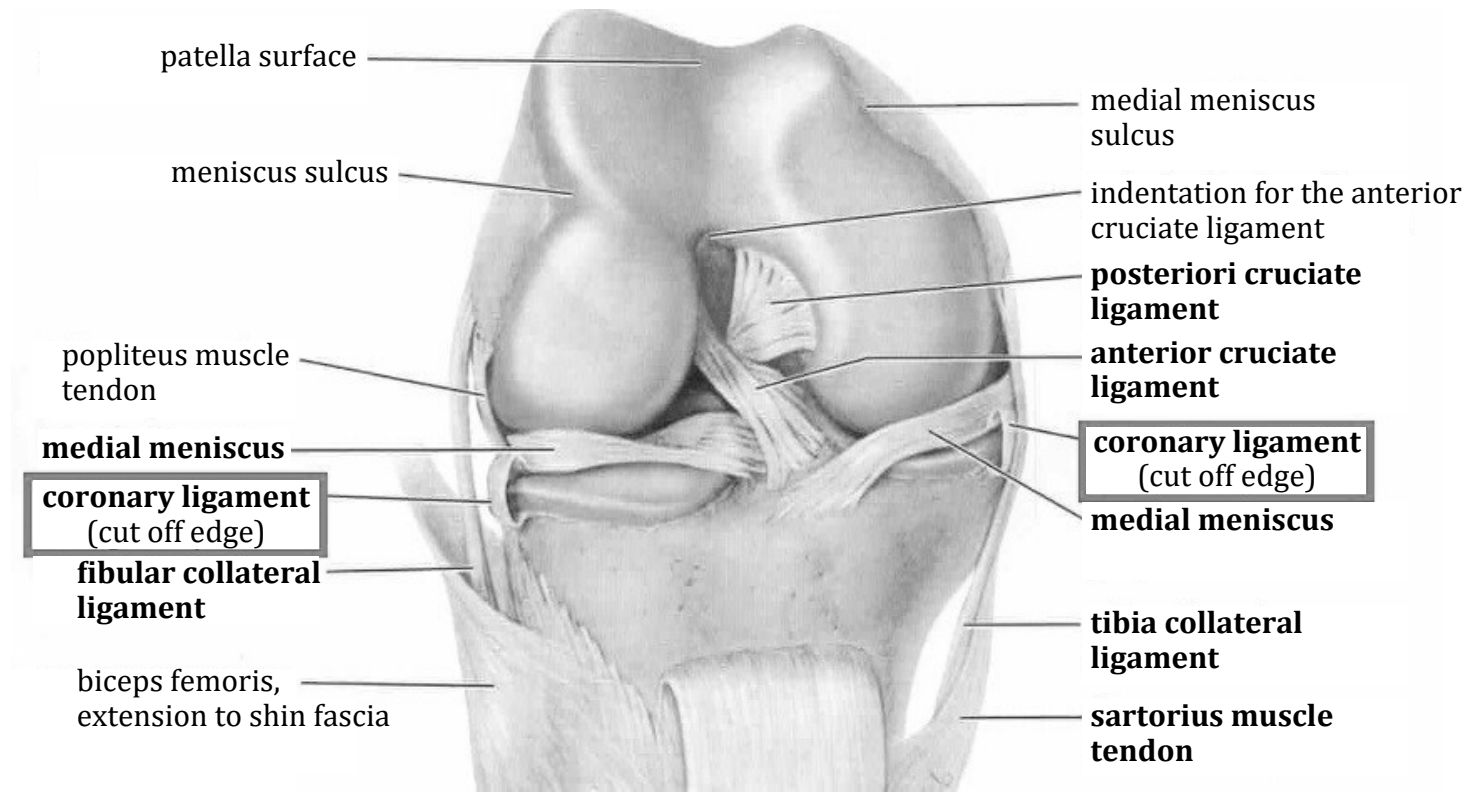

Figure 1. Medial and lateral meniscotibial ligament (MTL) [8]

Deep transverse friction massage (DTFM) is one of the manual treatment methods described by James Cyriax. It aims at maintaining tissue mobility and preventing the occurrence of adhesion and scars on the healing structure. The name of the method derives from the direction in which it is done - transversally to the fibers of the treated tissue - and high intensity of the massage. DTFM may be applied from the fourth day after the injury. It is recommended to do 2-3 procedures per week during which the time of procedure is systematically extended from 2 to 15 minutes. DTFM operates on the analgesic effect, increasing the blood flow in the injured tissue and stimulation of the correct orientation of the forming fiber of the connective tissue. Contraindications for this method include skin diseases, inflammation, varices in the place where the procedure should be applied and coexisting rheumatic syndromes $[10,13]$.

The paper aims at the presentation of the effectiveness of deep transverse friction massage (DTFM) in the treatment of injury to the medial meniscus-tibial ligament in a female football player.

\section{Case description}

The patient was a 22-year-old female (body weight $58 \mathrm{~kg}$, body height $162 \mathrm{~cm}$ ), a football player at AZS Biała Podlaska Sports Club, Poland, who has been training and playing on the position of striker for three years. The patient indicated the right lower limb as the dominant. The patient has been experiencing and informing about pain in the medial part of the right articulatio genus during walking and running. The patient does not recall the situation in which a direct injury might have happened. The first symptoms occurred while making sudden changes in the direction of running during training. Three weeks prior to the symptoms, the patient experienced similar symptoms but they receded an hour after the physical effort. 
The patient underwent ultrasonography carried out by a radiologist with the BK Medical device and 18L5, 10L2w head. The test examination showed swelling and hyperemia within the connective tissue of the medial meniscus. The remaining structures did not show features of injury.

\section{Treatment}

Deep transverse friction massage (DTFM) was applied in the treatment. The procedure was carried out in the position of a bent articulatio genus of the patient to $90^{\circ}$ and external rotation of the shin. The therapist put their second finger with the third finger over it on the medial part in the joint space of the articulatio genus. The therapist's forearm was placed in pronation ensuring that the second finger was touching MTL on the surface of the plateau of tibia. The massage was carried out in transversally to the MTL fibers in the rhythm of one movement per second (Figure 2) [14]. The treatment was started on the fifth day after the occurrence of the symptoms. A total of 9 procedures was conducted (3 times a week) throughout three weeks. The first DTFM session lasted 2 minutes and the time was systematically extended during further sessions by 1-2 minutes until it reached 15 minutes.

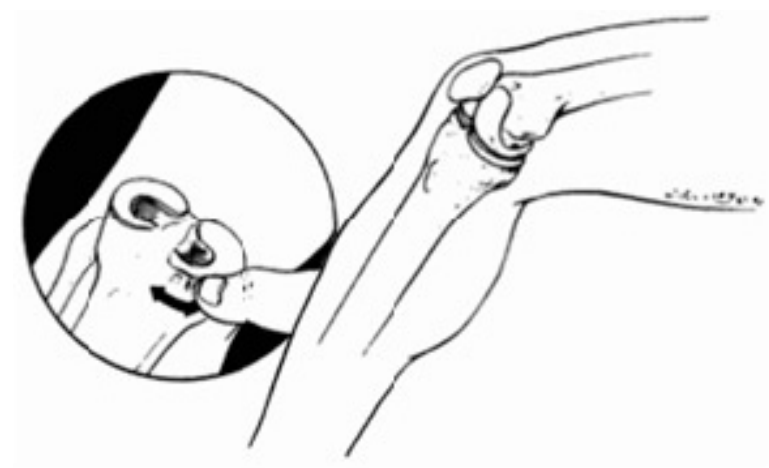

Figure 2. Deep transverse friction massage of the medial meniscotibial ligament [14]

\section{Research tools}

The following research tools were applied to evaluate the effectiveness of DTFM treatment:

1. Visual Analogue Scale (VAS)- subjective evaluation of pain intensity level in the form of a scale from 0 (lowest pain) to 10 (strongest pain);

2. Modified Laitinen Pain Questionnaire which considers four indicators evaluated on the scale from 0 to 4 : pain intensity, pain frequency, the use of analgesic medication, and limitation of patient's motor activity. The patient could obtain from 0 to 16 points in which the highest result means the highest pain level. The patient evaluated pain during everyday activities;

3. External passive rotation test during which the patient is lying on the back while the articulatio genus is bent at the degree of $110^{\circ}$. The therapist grasps the articulatio genus from the top placing fingers in the joint fissure to palpate the movement. They grasp the patient's foot with the other hand, introduce the maximal dorsiflexion in the upper articulation talocruralis, and perform the maximal external rotation on the articulatio genus, provoking symptoms in the MTL area [10]. The pain level was evaluated with VAS;

4. The modified articulatio genus line tenderness test during which the patient is lying on the back and articulatio genus of the patient is bent to $90^{\circ}-110^{\circ}$ [15]. The modification concerns the placement of the person conducting the test and the direction of pressure put on the joint structures. The therapist examines the frontal-medial fissure line of the articulatio genus with the side of their thumb pushing meniscotibial ligament to the articular surface of the tibia [10]. The pain level was evaluated with VAS;

5. Load distribution test of lower limbs on the GAMMA dynamometric platform in the form of countermovement jump test with arm swing (CMJ) - the patient is standing with feet placed shoulderwidth apart, each foot on the separate plate of the platform. Then the patient was asked to jump up with the preceding fast bend in the knees and arms swing. The landing should occur on the same platforms as takeoff. The activity was repeated five times. The analysis concerned three phases of the test - jump, landing, and stabilization with the exclusion of the flight phase. Limb symmetry index (LSI) calculated based on data obtained from two platform plates (weight test) was applied in the evaluation of lower limb load distribution. The measure of 1.0-1.15 was assumed to be the correct index value [16]. 
To rule out the injury to the tibial collateral ligament and tibial meniscus the following tests were carried out in physical examination:

- Valgus stress test which is conducted while the patient is lying on the back. In the first phase of the test, the therapist performs passive adduction of shin with articulatio genus bent at the angle of $20^{\circ}$. The range of motion, the level of opening of the articular fissure, and end sensation are assessed. In the second phase of the examination, the test is repeated in full extension of the articulatio genus [17];

- Articulatio genus line tenderness test during which the patient is lying on the back while the articulatio genus is bent at the degree of $110^{\circ}$. The therapist palpates the length of the knee fissure line with the side of the thumb. The positive symptom of the test is experiencing a high level of stabbing pain [15];

- McMurray's test during which the patient is lying on the back and the articulatio genus and articulatio coxae are firmly bent. The therapist grasps the patient's articulatio genus with one hand and metatarsus with the other. Then, the therapist firmly rotates the patient's shin externally and extends the articulatio genus. Pain experienced during this test may be a symptom of an injury to medial meniscus [15].

The evaluation employing VAS and Laitinen Pain Questionnaire was conducted four times - before introducing the treatment as well as after the first, second, and third week of treatment. Measurements on the dynamometric platform were conducted twice - before introducing DTFM treatment and after 3 weeks of sessions.

\section{Results}

During the examination carried out before introducing the treatment of the valgus stress test, articulatio genus line tenderness test and McMurray's test were negative.

The level of pain evaluated utilizing VAS was decreased after three weeks of treatment from 7 to 0 in the shin external passive rotation test, from 9 to 3 in the modified articulatio genus line tenderness test and from 5 to 0 during everyday activities. Detailed test results in respective phases of examination were presented in Figure 3.

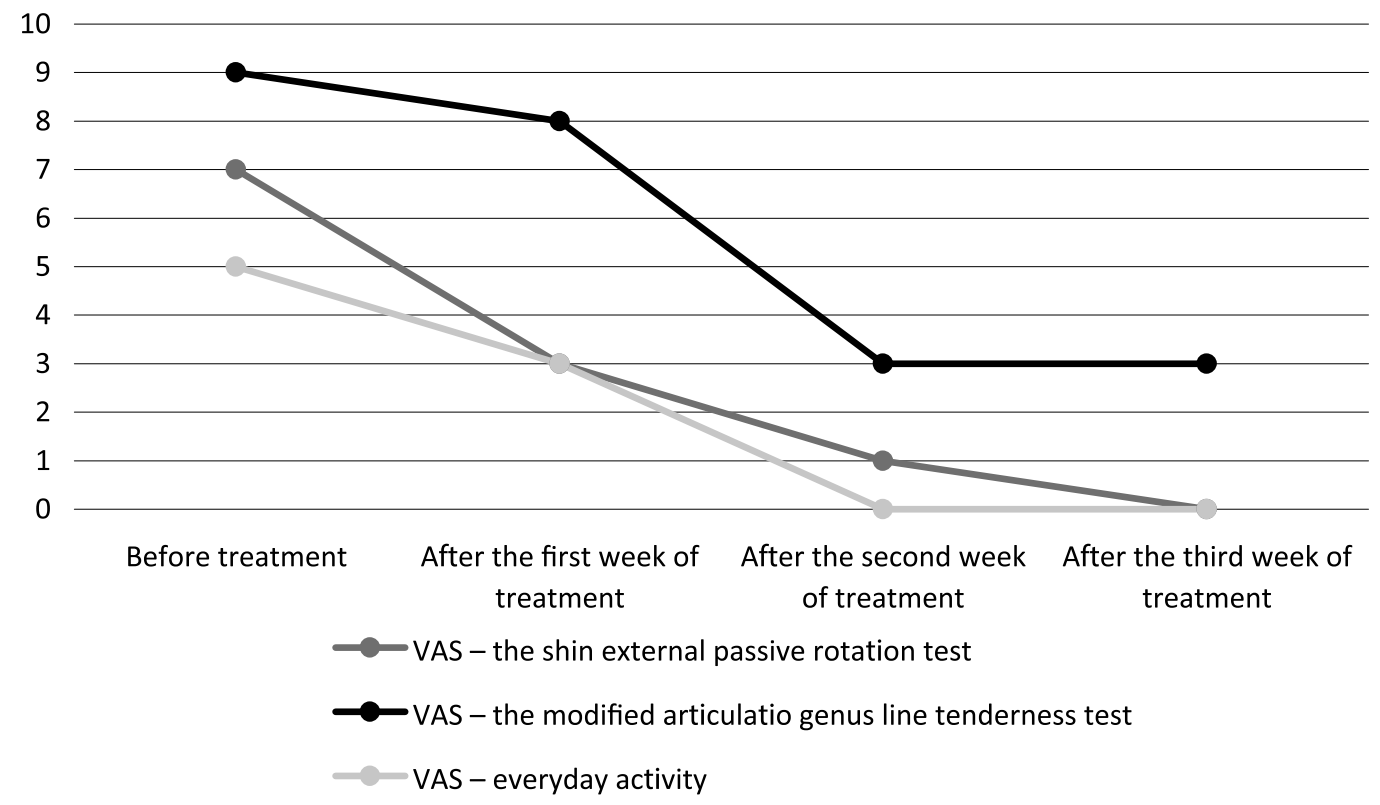

Figure 3. The change in pain level evaluated with VAS

The level of pain measured utilizing the modified Laitinen Pain Questionnaire decreased from 9 points before introducing the treatment to 0 points after 3 weeks of therapy. Detailed results in respective phases of examination were presented in Table 1. 
Table 1. The change in pain measured utilizing the modified Laitinen Pain Questionnaire

\begin{tabular}{|c|c|c|c|c|c|c|}
\hline & Pain evaluation & Points & $\begin{array}{c}\text { Before } \\
\text { treatment }\end{array}$ & $\begin{array}{c}\text { After } 1^{\text {st }} \text { week } \\
\text { of treatment }\end{array}$ & $\begin{array}{c}\text { After } 2^{\text {nd }} \\
\text { week of } \\
\text { treatment }\end{array}$ & $\begin{array}{c}\text { After } 3^{\text {rd }} \text { week } \\
\text { of treatment }\end{array}$ \\
\hline Pain intensity & $\begin{array}{l}\text { Pain free } \\
\text { Mild } \\
\text { Strong } \\
\text { Very strong } \\
\text { Beyond bearing } \\
\end{array}$ & $\begin{array}{l}0 \\
1 \\
2 \\
3 \\
4\end{array}$ & 3 & 2 & 1 & 0 \\
\hline $\begin{array}{c}\text { Frequency } \\
\text { of pain } \\
\text { occurrence }\end{array}$ & $\begin{array}{l}\text { Does not occur } \\
\text { Intermittenly } \\
\text { Often } \\
\text { Very often } \\
\text { Chronic pain } \\
\end{array}$ & $\begin{array}{l}0 \\
1 \\
2 \\
3 \\
4\end{array}$ & 3 & 1 & 1 & 0 \\
\hline $\begin{array}{l}\text { Use of analgesic } \\
\text { medication }\end{array}$ & $\begin{array}{l}\text { No medication } \\
\text { Extemporaneously } \\
\text { Continously, small } \\
\text { doses } \\
\text { Continously, large } \\
\text { doses } \\
\text { Continously, very } \\
\text { large doses } \\
\end{array}$ & $\begin{array}{l}0 \\
1 \\
2 \\
3 \\
4\end{array}$ & 1 & 0 & 0 & 0 \\
\hline $\begin{array}{l}\text { Limitation } \\
\text { to physical } \\
\text { activity }\end{array}$ & $\begin{array}{l}\text { None } \\
\text { Partial } \\
\text { Preventing work } \\
\text { Requiring partial } \\
\text { help } \\
\text { Requiring } \\
\text { complete help } \\
\end{array}$ & $\begin{array}{l}0 \\
1 \\
2 \\
3 \\
4\end{array}$ & 2 & 1 & 0 & 0 \\
\hline \multicolumn{3}{|c|}{ TOTAL } & 9 & 4 & 2 & 0 \\
\hline
\end{tabular}

After completing the physiotherapeutic treatment improvement of the limb symmetry index in all phases of countermovement jump with arm swing was observed (Table 2). The most significant improvement was noted in the bounce phase in which the limb symmetry index decreased from 1.24 to 1.03 after three weeks of therapy.

Table 2. Limb symmetry index values in the applied tests before and after the therapy

\begin{tabular}{|c|c|c|c|c|c|c|}
\hline $\begin{array}{c}\text { Test of } \\
\text { countermovement } \\
\text { jump with arm } \\
\text { swing (CM) }\end{array}$ & $\begin{array}{c}\text { Right lower } \\
\text { limb load (\%) }\end{array}$ & $\begin{array}{c}\text { Left lower } \\
\text { limb load (\%) }\end{array}$ & $\begin{array}{c}\text { Limb } \\
\text { symmetry } \\
\text { index }\end{array}$ & $\begin{array}{c}\text { Right lower } \\
\text { limb load (\%) }\end{array}$ & $\begin{array}{c}\text { Left lower } \\
\text { limb load (\%) }\end{array}$ & $\begin{array}{c}\text { Limb } \\
\text { symmetry } \\
\text { index }\end{array}$ \\
\hline Takeoff phase & 42.9 & 53.1 & 1.24 & 46.9 & 50.7 & 1.03 \\
\hline Landing phase & 43.5 & 56.5 & 1.29 & 49.3 & 53.1 & 1.13 \\
\hline Stabilization phase & 46.3 & 53.7 & 1.16 & 48.8 & 51.2 & 1.05 \\
\hline
\end{tabular}

\section{Discussion and conclusions}

Injuries to medial meniscotibial ligament may be mistaken by the diagnostician for the injury to a medial meniscus-tibial ligament (MCL) and medial meniscus. There is also a possibility of the occurrence of combined injuries. The differentiation of the injured structures employing functional tests such as the valgus stress test, articulatio genus line tenderness test, and McMurray's test may be helpful. In the case of diagnostic uncertainties, additional examinations like ultrasonogram (USG) and magnetic resonance imaging (MRI) may be performed [7].

This is the first study of the application of DTFM in the treatment of medial meniscotibial ligament. Papers assessing the effectiveness of DTFM in the treatment of wrist extensor enthesopathy, iliotibial band syndrome, and patellar ligament tendinopathy are prevailing in the available literature [18-21]. 
In the described case study the application of deep transverse friction massage resulted in a decrease in pain levels discernible already after the first week of treatment ( 3 sessions). The pain level was measured utilizing VAS and Laitinen Pain Questionnaire. After three weeks of DTFM, the level of pain amounting to 3 in VAS remained only in the palpation test of the ligament. The patient did not report pain during regular, everyday activities.

Injuries to lower limbs may result in the alteration in activity patterns and shifting of the center of gravity to the healthy limb. Even after curing the injury, the incorrect activity pattern may remain and cause prolonged biomechanical disorders [22].

The asymmetry of lower limbs concerning muscle strength and endurance becomes a research topic in many professional sport disciplines more frequently [23]. One of the parameters used to evaluate the level of effectiveness of DTFM treatment was the load symmetry index of lower limbs during three phases of a countermovement jump with arm swings. The measure of 1.0-1.15 was assumed to be the correct index value. The research reports the largest disturbance to the index during takeoff (1.24) and landing (1.29). This was connected with the most noticeable pain reported by the patient. After completing the treatment the index in both phases was positioned within the range (landing - 1.03, takeoff-1.13). Still, more weight was put in the healthy (left) limb yet the index value was within the norm.

Limb symmetry index may be considered as a factor of the prevention of injuries and degenerative changes connected with incorrect placement of lower limbs [24]. The research shows that the index may also be used as an assessment tool for the level of treatment effectiveness and progress of rehabilitation.

The results demonstrate that DTFM may be an effective method of treatment for MTL injuries. Therefore, the author finds it necessary to continue research using a larger patient cohort.

\section{References:}

1. Jacobson I, Tegner Y. Injuries among Swedish female elite football players: a prospective population study. Scand J Med Sci Sports. 2007; 17(1): 84-91. https://doi.org/10.1111/j.1600-0838.2006.00524.x

2. Junge A, Dvorak J. Injuries in female football players in top-level international tournaments. Br J Sports Med. 2007; 41(suppl 1): 3-7. https://doi.org/10.1136/bjsm.2007.036020

3. Fortington LV, Donaldson A, Finch CF. Self-reported worst injuries in women's Australian football identify lower limb injuries as a prevention priority. BMJ Open Sport Exerc Med. 2016; 2(1): 2-8. https://doi.org/10.1136/bmjsem-2016-000112

4. Jones A, Jones G, Neil G, Bower P, Brown J, Hind K, et al. Epidemiology of injury in English professional football players: a cohort study. Phys Ther Sport. 2019; 35: 18-22. https://doi.org/10.1016/j.ptsp.2018.10.011

5. Webb J, Corry I. Epidemiology of knee injuries: diagnosis and triage. Br J Sports Med. 2000; 34: $227-228$.

6. Lougher L, Southgate CRW, Holt MD. Coronary ligament rupture as a cause of medial knee pain. Arthroscopy: The Journal of Arthroscopy \& Realted Surgery. 2003; 19(10): 157-158. https://doi.org/10.1016/j.arthro.2003.10.027

7. Zaworski K, Wójcik G, Rutowicz B. Traumatic injury of medial meniscotibial ligament - diagnostics and conservative treatment. Acta Balneologica. 2020; 159(1): 16-21.

8. Moore KL, Dalley AF, Agur AMR. [Clinically oriented anatomy]. Wrocław: MedPharm Polska; 2017 (in Polish).

9. Schulte E, Schunke M, Schumacher U. [Atlas of anatomy. General anatomy and musculoskeletal system]. Wrocław: Wydawnictwo MedPharm; 2013 (in Polish).

10. Cyriax JH. [Cyriax's illustrated manual of orthopaedic medicine]. Warsaw: DB Publishing; 2009 (in Polish).

11. Hudes K. Two cases of medial knee pain involving the medial coronary ligament in adolescents treated with conservative rehabilitation therapy. J Can Chiropr Assos. 2011; 55(2): 120-127.

12. Liu F, Gadikota HR, Kozanek M, Liu W, Gill TJ, Rubash HE, et al. Morphology of the medial collateral ligament of the knee. Journal of Orthopaedic Surgery and Research. 2010; 5: 69-77. https://doi.org/10.1186/1749-799X-5-69

13. Buckwalter JA. The effects of early motion on healing of musculoskeletal tissues. Hand Clin. 1996; 12(1): 13-24.

14. Hammer WI. Functional soft tissue examination and treatment by manual methods. Sudbury: Johnes and Barlett Publishers; 2005.

15. Smith BE, Thacker D, Crewesmith A, Hall M. Special tests for assessing meniscal tears within the knee: a systematic review and meta-analysis. Evid Based Med. 2015; 20(3): 88-97.

https://doi.org/10.1136/ebmed-2014-110160 
16. Drużbicki M, Kwolek A, Pop T. [Difficulties in rehabilitation after the fracture of the neck of femur in patients with neurological illnesses - description of cases]. Przegląd Medyczny Uniwersytetu Rzeszowskiego. 2006; 4: 292-297 (in Polish).

17. Buckup K, Buckup J. [Clinical tests for the musculoskeletal system]. Warszawa: PZWL; 2014 (in Polish).

18. Nagrale AV, Herd CR, Ganvir S, Ramteke G. Cyriax physiotherapy versus phonophoresis with supervised exercise in subjects with lateral epicondylalgia: a randomized clinical trial. J Man Manip Ther. 2009; 17(3): 171-178. https://doi.org/10.1179/jmt.2009.17.3.171

19. Loew LM, Brosseau L, Tugwell P, Wells GA, Welch V, Shea B, et al. Deep transverse friction massage for treating lateral elbow or lateral knee tendinitis. Cochrane Database Syst Rev. 2014; 11: CD003528. https://doi.org/10.1002/14651858.CD003528

20. Brosseau L, Casimiro L, Milne S, Welch V, Shea B, Tugwell P, et al. Deep transverse friction massage for treating tendinitis. Cochrane Database Syst Rev. 2002; 4: CD003528. https://doi.org/10.1002/14651858.CD003528

21. Chaves P, Simões D, Paço M, Silva S, Pinho F, Duarte JA, et al. Deep friction massage in the management of patellar tendinopathy in athletes: short-term clinical outcomes. J Sport Rehabil. 2019; 30: 1-6. https://doi.org/10.1123/jsr.2019-0046

22. Wilczyński J, Szaraniec K. The impact of medial gymnastics on load on the lower limb after knee twisting, on the basis of selected tests. Studia Medyczne. 2014; 30(1): 27-34. https://doi.org/10.5114/ms.2014.41995

23. Bishop C, Turner A, Read P. Effects of inter-limb asymmetries on physical and sports performance: a systematic review. J Sports Sci. 2018; 36(10): 1135-1144. https://doi.org/10.1080/02640414.2017.1361894

24. Golec J, Tomaszewski K, Masłoń A, Szczygieł E, Hładki W, Golec E. [The assessment of gait symmetry disorders and chosen body posture parameters among patients with polyarticular osteoarthritis]. Ostry Dyżur. 2013; 6(3): 91-95 (in Polish). 